\title{
On Defining, Assessing and Governing of Agrarian Sustainability
}

\author{
Hrabrin Bachev ${ }^{1^{*}}$ \\ ${ }^{1}$ Institute of Agricultural Economics, Sofia, Bulgaria \\ Email: hbachev@yahoo.com
}

\begin{abstract}
Research on governance of agrarian sustainability is at the beginning stage due to "newness" of the problem, emerging new challenges, fundamental modernization during recent years, "lack" of long-term experiences and relevant data, application of narrow (certain form/management level), one-dimensional, unisectioral, normative, without transaction costs etc. approaches. This paper suggests a modern and practical framework for analyzing and assessing the system of governance of agrarian sustainability. Interdisciplinary New Institutional Economics framework is incorporated and agrarian sustainability is properly defined, principle mechanisms and modes of governance (institutions, market, private, public, hybrid) of agrarian sustainability are classified, and a holistic approach for identifying components and factors, assessing efficiency, and improving governance system is presented. Framework is to be further discussed and improved while its application requires new type of micro and macro-economic data for agrarian agents' preferences and behavior, activities and efficiency of farming organizations, effects and impacts on social, community and natural environment, etc.
\end{abstract}

Keywords: Agrarian sustainability, market, private, public governance

\section{Introduction}

Achievement of diverse economic, social, environment conservation etc. goals of development greatly depends on the specific system of governance in different countries, industries, regions, communities, etc. $[1,2,3,4,5,6,7]$. Having in mind the importance of agrarian sector (in terms of employed resources, contribution to individuals and social welfare, positive and/or negative impacts on environment, etc.), the improvement of the governance of agrarian sustainability is among the most topical issues in EU and around the globe $[1,8,9,10,11,12,13,14,15,16,17,18,19,20,21,22,23,24,25,26]$.

Research on forms and efficiency of the governance of agrarian sustainability is at the beginning stage due to the "newness" of the problem, and the emerging new challenges at the current phase of development (environmental pollution and degradation, climate change, competition for natural resources with other sectors), and the fundamental institutional modernization during recent years, and the "lack" of long-term experiences and relevant data, etc.

Most studies in the area are focused on formal modes and mechanisms while the important informal institutions and organizations are not included into analysis. What is more, research is commonly restricted to a certain form (contract, cooperative, industry initiative, public program), or a management level (farm, eco-system, region) without taking into consideration the interdependency, complementarities and/or competition of different governing structures. Besides, widely used complex forms of governance (multi-lateral, multi-level, reciprocial, interlinked, and hybrid modes) are usually ignored.

Likewise, one-dimensional and uni-sectoral analyses are broadly used separating the management of agricultural activity from the governance of environmental and overall households and rural activities. Furthermore, most studies concentrate on production costs ignoring significant transaction costs associated with the identification, assignment, protection, exchange and disputing of diverse property rights and rules. Moreover, "normative" (to some "ideal" or "model in other countries") rather than a "comparative institutional approach" (between feasible alternatives in the specific socio-economic and natural conditions of a country, region, sector, ecosystem) is employed. 
Furthermore, uni-disciplinary approach dominates ("pure economic", "pure ecological", "pure political" etc.) preventing a proper understanding of the driving factors ("logic") and the full consequences (multiple effects, costs, risks) of a particular governance choice. Consequently, a complete understanding and adequate assessment of the system of governance of agrarian sustainability is impeded.

The goal of this paper is to suggest a modern and practical framework for analysing and assessing the system of governance of agrarian sustainability. First, agrarian sustainability is properly defined. After that principle mechanisms and modes of governance of agrarian sustainability are classified. Next, an approach for identifying the components and factors, assessing the efficiency, and improving the system of governance is presented. Ultimate objective of this study is to assist public policies and forms of intervention as well as farming, business and collective actions for sustainable agrarian development.

\section{Defining Agrarian Sustainability}

In the literature and managerial practice there are diverse approaches for defining agrarian sustainability - as an alternative ideology [15,26]; as a new (set of) strategy/ies [21]; as characteristics of agrarian systems - e.g. "ability to satisfy a diverse set of goals through time" [27,28], "ability (potential) of the system to maintain or improve its functions" [29,30]; as a "process of learning about changes and adapting to these changes" [23], etc.

Definition of agrarian sustainability has to be based on the "literal" meaning of that term and perceived as system characteristics and "ability to continue through time". It is a feature of agricultural activity - production associated with cultivation of animals, plants, fungi, and other life forms for human and livestock food, raw materials for processing industries, bioenergy, medicinal and other products and services. Its important feature is the management and utilization of agro-ecosystems of different types (plain, mountainous, riverside, seaside, open-air, closed, etc.), and the "responsibility" for their preservation for future generations.

The characterization of sustainability has to be "system-oriented" while the system is to be clearly specified, including its time and spatial boundaries, components, functions, goals, and importance in the hierarchy. That implies taking into account the diverse socio-economic and environment conservation functions of agrarian sector, the type and efficiency of agrarian organization, and the mutual links (importance, dependency, complementarity) of different governance and organizational structures, and relations with sustainability of households, region, eco-system and the entire sector (industry).

Sustainability has to reflect both the internal capability of agriculture to function and adapt to the external impact of constantly evolving socio-economic and natural environment. However, the features of relatively independent (sub)systems are to be well distinguished - e.g. while "satisfaction from farming activity" is an important social attribute of agrarian sustainability, the modernization of social infrastructure and services in rural areas is merely a prerequisite (factor) for the long-term sustainability of farms and agrarian sector.

Incorporated internal dynamism of the systems also implies an "end life" (there is no system which is sustainable forever) as a particular agrarian system is considered to be sustainable if it achieves (realizes) its "expected lifespan" [23]. For instance, if due to the augmentation of farm households' income the number of subsistence and part-time farms is decreasing while agrarian resources are effectively transferred to other structures, this process should not be associated with a negative change in sustainability. On the other hand, if farms of a particular type and sector are not able to adapt to the dynamic economic, institutional and climate changes through adequate modernization in technology, product, and organization, their sustainability is low.

Characterization of sustainability must also be predictive since it deals with future changes rather than the past and only the present. In addition, sustainability has to be a criterion for guiding changes in policies, and farming and consumption practices, agents' behaviours, for focusing of research and development priorities, etc. In that sense, the analysis of the levels and factors of "historical" sustainability of farms of certain type and specialization, particular agro-ecosystems or regions, or entire sector ("achieved level of sustainability") is extremely useful for the theory and practice. The assessments of past states help identify critical factors and trends in sustainability of farms and industry, and undertake efficient measures for its improvement by managers, stakeholders, state authority, etc. 
Sustainability is to allow facile and rapid diagnostic, and possibility for intervention through identification and prioritizing restrictions, testing hypothesis, and giving possibility for comprehensive assessments. Since most system are difficult to comprehend, calculate, and monitor in everyday activity [31], agrarian sustainability is to be easy to understand and practical to use by agents without being associated with huge costs.

Agrarian sustainability characterizes the ability of agriculture to maintain its economic, ecological and social functions in a long-term. Agriculture "produces" multiple products, "private" and "public" goods (food, rural amenities for hunting, tourism, landscape enjoyment), environmental and cultural services, habitat for wild animals and plants, biodiversity, including less desirable ones such as waste, harmful impacts etc. All these functions of agrarian production are to be taken into account as sustainable agriculture must be economically sustainable, and ecologically sustainable, and socially sustainable.

Agrarian sustainability has three aspects which are equally important and have to be always taken into account. Agriculture is sustainable if it is

- economically viable and efficient - i.e. provide enough employment and income for farm and rural households, good or high productivity and utilization of natural, personal, material, and financial resources, economic efficiency and competitiveness, and financial stability of activity;

- socially responsible regarding farmers, workers, other agents, communities, consumers and society i.e. contribute to amelioration of welfare and living standards of farmers and rural households, conservation of agrarian resources and traditions, and sustainable development of rural communities and society;

- ecologically sustainable - i.e. activity is associated with conservation, recovery and improvement of components of natural environment (landscape, lands, waters, biodiversity, atmosphere, climate, etc.), respecting "rights" of farm and wild animals ("animal welfare"), etc.

Depending on the combination of all these dimensions, in a particular moment or period of time, agriculture could be with a high, good, or insufficient sustainability, or unsustainable. Agriculture may have a high economic sustainability, and a low ecological and social sustainability, and vice versa. Nevertheless, low (lack of) sustainability in any of the aspects (pre)determines the overall level in the long-term.

The level of agrarian sustainability is to be evaluated in a short-term (programing period), midterm (current generation of farmers) and long-term (next generation) scales.

The level of agrarian sustainability is to be evaluated at different levels: sector, ecosystem, administrative region, and farm. The farm is the lowest level, where management and organization of agricultural activity is carried out, and where all three aspects of agrarian sustainability are "realized" and could be assessed. Estimates (mainly ecological, some economic) on an inter-farm level (parcel, section, ecosystem, division) are useful for improving sustainability of a particular holding, but only partially characterize sustainability of the entire farm and are insignificant for the overall sustainability of agrarian sector ${ }^{1}$. Intra-farm assessments on economic, social and ecological aspects of sustainability are more important for larger holdings with a big membership (coalition partners, hired labour), internal organization ("autonomous" divisions), and wide space dislocation and diversity of their activity.

The assessment of agrarian sustainability has to be always made for the specific socio-economic and ecological, rather than an unrealistic (desirable, "normative", ideal) context. In that sense, employment of any "Nirvana approach" for determining sustainability criteria (not related to the specific environment "scientific" norms; model of farming in other regions or countries; assumptions of perfectly defined and enforced rights and rules; situation without missing markets and public interventions) is not correct [10]. For example, in EU respecting the "rights" of farm livestock ("animal welfare"), and maintaining ecosystem services (preservation of landscape, culture and traditions) are substantial attributes of agrarian and farm sustainability.

In each particular stage of the evolution of individual countries, communities, eco-systems, sub-sectors and farms, there is specific knowledge for agrarian sustainability (e.g. links between human activity and climate change), individual and social value system (preferences for "desirable state" and "economic value" of natural resources, biodiversity, human health, preservation of traditions), resource endowment and possibilities, institutional structure (rights on clean nature and biodiversity, of vulnerable groups,

\footnotetext{
${ }^{1}$ Many systems for assessing agrarian sustainability are based on estimates for individual parcels of land, while higher levels are aggregated results of basic indicators [24].
} 
producers in developing countries, future generations, animal welfare), and goals of socio-economic development.

Understanding, content, and assessment of agrarian sustainability are always specific for a particular historical moment and socio-economic, institutional and natural environment. For instance, many otherwise "sustainable" farms in East Europe were not able to comply with high EU standards for quality, safety, ecology, animal welfare etc. and ceased to exist or entered "unsustainable" grey sector of economy ${ }^{2}$.

Taking into account the external socio-economic and natural factors helps to determine major factors contributing to agrarian sustainability - competition with imported products, on international markets, for resources with other sectors; evolution of farming and agrarian organizations, access and extent of public support, extreme climate, diseases on animals and crops, growth in income and demand, etc.

\section{Defining and Agents of Governance of Agrarian Sustainability}

Maintaining social, economic and ecological functions of agriculture requires an effective social order ("good governance") - a system of mechanisms and forms regulating, coordinating, stimulating, and controlling behaviours, actions and relations of individual agents at different levels (Figure 1).

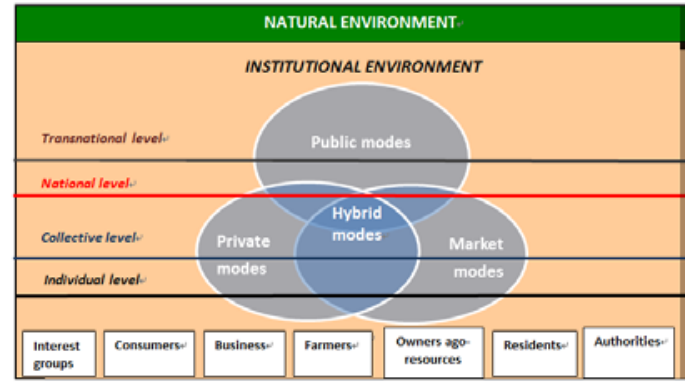

Figure 1. Modes and levels of governance of agrarian sustainability

The system of governance of agrarian sustainability is a part of the specific system of governance of agrarian development, and includes: diverse agrarian and non-agrarian agents, and a variety of mechanisms and forms for governing of behavior, activity, relations, and impacts of agents. The (entire) system of governance and its individual components are to be evaluated, including: diverse agents participating in the governance of economic, social and ecological aspects of agrarian sustainability; and diverse mechanisms and forms "managing" behavior and relations of these agents.

Initially, agents of the governance of agrarian sustainability and the specific character of their relations, interests, objectives, capabilities, power positions, dependences, effects, and conflicts are to be identified. The farm is the main organizational and production unit in agriculture, which manages resources, technologies and activity, and maintains social, economic and ecological functions of the sector. Thus, farms and farm (production, service, innovation, marketing) organizations are major elements of the system of governance of agrarian sustainability.

Farms of different type (subsistent, part-time, commercial, member oriented, organic, etc.) have unlike potential for maintaining social, economic, and ecological functions of agriculture. They have different goals for existence - supplementary or main income, profit, free time occupation, preservation of nature or farm for future generations, etc. Most farms also have unequal incentives and capabilities (resources, knowledge, positions) for achieving agrarian sustainability. In one-person holding (ownerfarmer) there is a "complete" conjunction of social, economic and ecological goals, and possibility for "self-management", but often insufficient capability (size, resources, positions) for accomplishing all functions in effective scale. Complex farms (partnerships, cooperatives, corporations, public) and organizations with a big membership have greater capability, but also "internal" conflicts of interests

\footnotetext{
${ }^{3}$ Most assessment systems apply "universal" approach for "faceless" farms and agriculture, without taking into consideration the specificity of holdings and sector, and the environment in which they function.
} 
and incentives of different agents (owners, managers, members, hired labor). That necessitates a special "mechanism" for coordination and motivation of activity, harmonization of interests, resolution of conflicts etc. of agents for achieving agrarian sustainability.

Other agents also directly or "indirectly" participate in the governance of agrarian sustainability imposing appropriate conditions, standards, norms, demand, etc. These are the owners of agrarian (land, material, finance, intellectual) resources, who are interested in effective utilization and conservation. Next that is related business (suppliers of inputs, finance, technologies, buyers of farm produces) and final consumers. They all impose socio-economic and ecological standards, specific support and demand for sustainable agrarian activity. For instance, a significant portion of food processing companies and retail chains implement own strategies and (voluntary and/or mandatory) standards for "sustainability", which are private initiatives, common for industry "codes of behavior", or result of consumers demand for industrial "contribution" to agrarian sustainability.

Next, there are residents, visitors of rural areas, and diverse interests groups, which "impose" conditions (pressure, demand) for environmentally friendly, socially responsible, and economically viable agriculture and rural regions. Finally, there are state and local authorities, international organizations, etc., which assist initiatives for agrarian sustainability of different agents, and/or impose mandatory (social, economic, environmental) standards for sustainable production and consumption.

\section{Mechanisms and Forms of Governance}

A great part of agrarian activity is fully governed in a "decentralized" way by the individual (private) actions of independent agents (farms, suppliers, buyers, consumers) and market competition ("invisible hand of market"). For instance, the optimal resources distribution is "directed" and motivated by (free) market prices movement, farmers adapt production and technologies to market needs/demand, low efficiency is "punished" by insufficient profit, failure, outside take over, etc. However, when property rights are not well defined and enforced, and transaction costs are high, market governance does not achieve maximum efficiency (output, welfare, sustainability) [32]. Effective governance in agriculture usually necessitates concerted (collective) actions of a certain number of farms as it does in the case of sustainable use of a common pasture, limited water supply, protection of local biodiversity, etc.

Farming activity is also associated with significant positive and/or negative externalities, and production of multiple collective, quasi-public and public "goods and bads". All these require a special governance of relations (cooperation, conflict resolution, costs recovery) between different farms as well as farmers and non-farmers. For example, adverse effects of agricultural activities on water and air quality are often felt by residents and businesses in neighbourhood or other regions. Minimization of negative effects is achieved through effective "public intervention" - regulation, control, and sanctions by local and/or state authority [33].

Modern agrarian governance frequently requires "management" of collective actions of agents with diverse interests, power relations, awareness, capabilities etc. in large geographical, sectoral, and temporal scales, as well as additional actions and integral management of social, economic, and natural resources at regional, national and transnational scale. It is associated with the needs for "balanced" development of rural areas and communities, and "management" of major natural resources and risks (waters, biodiversity, climate change), demanding effective regional, nationwide, international, and global management, coordination and control.

The system of governance of agrarian sustainability includes a number of distinct mechanisms and modes, which manage behaviour and actions of individual agents, and eventually (pre)determine the level of agrarian sustainability (Figure 1):

First, institutional environment ("rules of the game") -the distribution of rights and obligations between individuals, groups, and generations, and the system(s) of enforcement of these rights and rules [34]. The spectrum of rights comprises material assets, natural resources, intangibles, activities, working conditions and remuneration, social protection, clean environment, food and environmental security, intra- and inter-generational justice, etc. The enforcement of rights and rules is carried out by the state, community pressure, trust, reputation, private modes, or self-enforced by agents.

A part of rights and obligations is constituted by formal laws, official regulations, standards, court decisions, etc. Usually there is a strict state regulation for ownership, usage, trade etc. of agricultural 
lands and other natural resources, mandatory standards for safety and quality of products, working conditions, environmental protection, animal welfare, etc. In addition, there are important informal rights and rules determined by tradition, culture, religion, ideology, ethical and moral norms, etc. In some East European countries many of the formal rights and rules 'do not work' well and the informal "rules of the game" predetermine ("govern") agents behaviour and a huge informal ("grey", "black") sector dominates in these economies[10].

Institutional development is initiated by public (state, community) authority, international actions (agreements, assistance, pressure), and private and collective actions of individuals. It is associated with the modernization and/or redistribution of existing rights; and evolution of new rights and novel (private, public, hybrid) institutions for their enforcement. For instance, agrarian sustainability "movement" initially emerged as a voluntary (private) initiative of individual farmers, after that it evolved as a "new ideology" (collective institution) of agrarian and non-agrarian agents, and eventually was formally "institutionalized" as a "social contract" and part of the "new public order". The EU membership of East-European countries is associated with adaptation of modern European legislation (Acquis Communautaire) as well as better enforcement (outside monitoring, and sanction of noncompliance by EU). At current stage of development many of the institutional innovations are results of the pressure and initiatives of interests groups (eco-association, consumer organizations, etc.).

Institutions and institutional modernization create unequal incentives, restrictions, costs, and impacts for individual aspects of agrarian sustainability. If the rights on natural resources are not well-defined or enforced, that leads to inefficient and unsustainable organization and exploration, constant conflicts among interested parties, and low economic, social and ecological sustainability, and vice versa. For instance, property rights on major agrarian resources (material assets, lands, waters) were not completely identified, transfected and enforced during most of the post-communist transition in Bulgaria. For a long period of time the management of a considerable portion of agricultural activity was carried out by "temporary" structures (Land Commissions, Liquidation Councils, Privatization Boards, tenancy farms based on a short-term lease, household farms for part-time employment). Consequently, a significant part of material, biological and intangible assets was destroyed, and low productivity, bad agro-technics, semi-market character, unsustainable exploitation of agricultural lands, and degradation of entire agri-ecosystems dominated [10].

In modern society formal and informal institutions (pre)determine to a great extent a considerable portion of the behaviour of agrarian and non-agrarian agents, and the level of agrarian sustainability. Nevertheless, there is no perfect system of preset "outside" rules and restrictions that can manage effectively the entire activity and behaviour of individuals in all possible and quite specific circumstances and relations of agrarian activity.

Second, market modes ("invisible hand of market") - various decentralized initiatives governed by the free market price movements and market competition - e.g. spotlight exchange of resources, products and services; classical purchase, lease or sell contract; trade of high quality, organic products and specific origins, agrarian and ecosystem services, etc.

Individual agents use (adapt to) markets, profiting from specialization of activity and mutually beneficial exchange, while their voluntary decentralized actions "direct" and "correct" overall distribution of resources between diverse activities, sectors, regions, ecosystems, countries. There are many examples for lack of individual incentives and choice and/or unwanted exchange, and unsustainable development in agrarian sector - missing markets, monopoly or power relations, positive or negative externalities, disproportion in incomes, and in working and living conditions between rural and urban regions, etc. Free market "fails" to govern effectively the overall activity and exchange in agrarian sphere, and leads to low socio-economic and ecological sustainability.

Third, private modes ("private or collective order") - diverse private initiatives, and special contractual and organizational arrangements (long-term supply and marketing contracts, voluntary ecoactions, voluntary or obligatory codes of behaviour, partnerships, cooperatives and associations, brads and trademarks, labels). For instance, conservation of natural resources is a part of the managerial strategy of many green (eco, green) farms. In EU there are numerous initiatives of farmer organizations, food industry, retail chains, and consumer organizations, which are associated with improvement of socio-economic and ecological sustainability.

Individual agents take advantage of economic, institutional and other opportunities, and deal with institutional and market deficiencies through selection or designing (mutually) beneficial private forms 
and rules for governing their behaviour, relations and exchanges. Private modes negotiate "own rules" or accept (impose) existing private or collective order, transfer existing rights or give new rights to counterpart(s), and safeguard absolute and/or contracted rights of agents. A great part of agrarian activity is managed by the voluntary initiatives, private negotiations, "visible hand of the manager", or collective decision-making. Nevertheless, there are many examples of private sector deficiency ("failures") in governing of socially desirable activity such as environmental conservation, preservation of traditional structures and productions, preservation and development of rural areas, etc.

Forth, public modes ("public order") - various forms of public (community, government, international) interventions in market and private sector such as public guidance, regulation, assistance, taxation, funding, provision, property right modernization, etc. For instance, in EU there are huge programs for agrarian and rural development aiming at "proportional" development of agriculture and rural areas, protection of incomes and improving the welfare of rural population, conservation of natural environment, etc.

The role of public (local, national, and transnational) governance increases along with the intensification of activity and exchange, and growing interdependence of socio-economic and environmental activities. In many cases, the effective management of individual behaviour and/or organization of certain activity through market mechanisms and/or private negotiation would take a long period of time and be very costly, could not reach a socially desirable scale, or could be impossible at all. Thus a centralized public intervention could achieve the desired state faster, more cheaply or more efficiently [10].

The public "participates" in the governance of agrarian sustainability through provision of information and training for private agents, stimulation and (co)funding of their voluntary actions, enforcement of obligatory order and sanctioning for non-compliance, direct organization of activities (state enterprise, scientific research, monitoring), etc. There are a great number of "bad" public involvements (inaction, wrong intervention, over-regulation, mismanagement, corruption) leading to significant problems of sustainable development around the globe.

Fifth, hybrid forms - some combination of the above three modes like public-private partnership, public licensing and inspection of private organic farms, etc.

In a long run the specific system of governance of agrarian sector and sustainability (pre)determines the type and character of social and economic development. Depending on the efficiency of system of governance of agrarian sustainability "put in place", individual farms, subsectors, regions and societies achieve quite dissimilar results in socio-economic development and environmental protection, and there are diverse levels and challenges in economic, social and ecological sustainability of farms, subsectors, regions and agriculture (Figure 2).

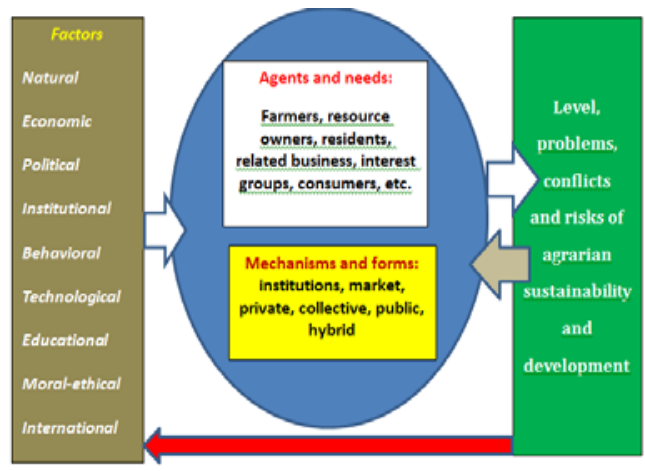

Figure2. Factors, forms and efficiency of governance of agrarian sustainability

\section{Identification of Dominant Mechanisms and Forms of Governance}

Governance "needs" are associated with the necessity for building adequate mechanisms and forms for stimulating, coordinating, directing, and harmonizing behavior and actions of interested agents, for 
maintaining economic, social, and ecological functions of agriculture, and revealing problems and risks associated with agrarian sustainability and its individual aspects.

Certain governing mechanisms and modes exist in the moment of assessment, since they are a part of the overall institutional environment or result of the "development" of market, private and public order in agrarian sphere. It is necessary to analyze to what extent managerial needs associated with major aspects of agrarian sustainability are "satisfied" by existing system of governance. Specific forms of governance of agrarian sustainability, which are used in the conditions of a particular farm, ecosystem, region, subsector, or agriculture, are to be identified and evaluated. For instance, integration of a farmer in the "organic" supply chain coordinates well relations between producers and final consumers, and contributes to economic and ecological sustainability. Nevertheless, the positive effect could be negligible, if simultaneously there is not an established mode for coordination of relations (collective actions) with other farmers in the region or a system for achieving required minimum scale for a positive eco-impact. Besides, needs of governance of social sustainability are not always satisfied effectively by introduction of organic production principles.

Analysis is to embrace the entire system of governance of agrarian sustainability, and characterize formal and informal institutions, market, private, collective and public forms of governance. The entire spectrum of "de-facto" (rather than "de-jure") rights on material and ideal assets (material and intellectual agrarian and eco-products), natural resources, certain activities, clean nature, food and ecosecurity, intra- and inter-generational justice, etc., which are related to agrarian sustainability, are to be scrutinized. Furthermore, efficiency of the enforcement system of rights and rules by the state, community pressure, trust, reputation, private and collective modes, is to be analyzed by agents themselves.

After that, an assessment is to be made: to what extent the institutional environment creates incentives, restrictions and costs for individual agents and society for achieving agrarian sustainability and its economic, social and ecological dimensions, intensifying exchange and cooperation between agrarian agents, increasing productivity of resource utilization, inducing private and collective initiatives and investments, developing new rights, decreasing divergence between social groups and regions, responding to socio-economic and ecological challenges, conflicts and risks, etc.

Next, various market forms of governance of agrarian activity are to be specified, and the extent to which "free" market contributes to coordination (direction, correction) and stimulation of agrarian activity and exchange, and effective allocation and utilization of agrarian (material, finance, intellectual, natural, etc.) resources is to be analyzed. Market governance is effective for an immense portion of activity and transactions in agrarian sector, since it is characterized with many participants, standard products, "free" competition and price formation, high frequency of transactions and low specificity of assets [10]. Despite that there are numerous "failures" of market in governing of critical for agriculture activities such as innovations, long-term investments, infrastructural development, environmental protection. The latter are usually associated with a high uncertainty and risk, low frequency and appropriability, great specificity, insufficient size, etc.

It is necessary to identify all cases of market "failure" leading to insufficient individual incentives, impossibility for a choice or unwanted exchange, and deficiency for effective maintenance of economic, social and ecological functions of agriculture. For instance, many stallholders experience significant difficulties and costs of market exchange, often face situations of "missing" markets, monopoly or asymmetry trade positions, while the sector "produce" considerable positive or negative externalities, and serious social, economic and ecological challenges and risks.

After that it is necessary to analyze how and with what forms individual agents take advantage of economic, market, institutional etc. opportunities, and overcome existing restrictions and risks through choice or design of new (mutually) beneficial private or collective modes (rules, organization) for governing their activity and relationships. Agrarian sector has many diverse private organizations of different type based on contract agreements, quasi or complete (horizontal, vertical) integration in land, labor, finance, inputs supply, marketing of products, etc. For instance, collective marketing organization of farmers increases negotiation positions, decreases market uncertainty and risks for members, minimizes costs (searching of information, certification, promotion and marketing of product, contracting and enforcement, packaging, storage), and increases revenues (market prices and share) of marketing augmenting income, profitability and economic sustainability of farming activity. 
Rational (private) agents usually use and/or design such forms for governing of diverse activities and relations, which are the most efficient for the specific institutional, economic and natural environment, and which maximize their overall benefits (production, ecological, financial, transaction, social) and minimize their overall (production, transaction, etc.) costs [10]. However, the outcome of private optimization of management and activity is not always the most efficient allocation of resources in society and maximum possible sustainability. There are many instances of private sector "failure" in governing of socially desirable agrarian (economic, social, ecological) activity, which are to be identified and analyzed. For example, due to low possibility for protection ("low appropriability"), impossibility for achieving minimum efficient scale, and/or high costs for contract negotiation, monitoring, implementation and enforcement, the supply with eco-products cannot be effectively organized through private forms (internal organization, contract, association) [37].

After that, analysis is to be made on diverse forms of public "involvement" in agrarian management through provision of information and training for private agents, stimulation and (co)funding of their voluntary actions, imposition of obligatory order and sanctions for non-compliance, direct organization of activities (state enterprise, scientific research, monitoring, etc.). That analysis also has to include specific (economic, social, ecological) benefits and overall costs for individual agents and society related to particular public intervention. Often there are cases of public "failure" (inactions, wrong interventions, over-regulations, mismanagement, corruption) leading to significant problems for sustainable agrarian development. All these cases are to be identified and analyzed.

A great portion of employed agro-management modes are integral, and affect more than one aspects of agrarian sustainability. Besides, improvement of one aspect through a particular form is often associated with negative effects for other aspect, component or element. For instance, product or direct subsidies increase farms income and economic sustainability, but could lead to overall intensification and ecological problems, further differentiation of efficiency and sustainability of holdings. Thus, it is also necessary to take into account the overall efficiency of a particular form, particular "package" of instruments, or the system of management as a whole.

All existing and other practically feasible (potential) forms for agro-management is to be identified, analyzed and assessed, so are complementarities (mutual or multiplication effect) and contradictions between individual forms and mechanisms of agro-management specified. For instance, often private (eco)initiatives of individual agents are in "conflict" with each other and/or the interests of the third parties; usually, public, collective and private forms are mutually complementary, etc.

Analysis and assessment of the system of governance of agrarian sustainability is a complex, multifacet, and interdisciplinary process, requiring profound knowledge of advantages and disadvantages of diverse governance modes, and detailed characterization of their efficiency (benefits, costs, effects) in the specific conditions of each agrarian agent, holding, type of farms, ecosystem, subsector, region, etc. Here quantitative indicators are less applicable, and more often we should apply qualitative (Discrete structural) analysis of comparative advantages, disadvantages, and net benefits [35].

Identification and assessment of the specific forms and mechanisms of governance of agrarian sustainability at farm, ecosystem, regional and sectoral scales is an object of a separate microeconomic study. For instance Table 1 summarizes major forms of governing of agrarian sustainability in Bulgaria during post-communist transition and European integration.

Table 1. Evolution of system of governance of agrarian sustainability in Bulgaria

\begin{tabular}{|c|c|c|c|}
\hline Institutions & Private modes & Market Modes & Public modes \\
\hline \multicolumn{4}{|c|}{ Post-communist transition $(1989-2000)$} \\
\hline $\begin{array}{l}\text { Not well } \\
\text { defined eco- } \\
\text { rights and } \\
\text { rights on } \\
\text { resource rights, } \\
\text { bad } \\
\text { enforcement; } \\
\text { Lack of concept }\end{array}$ & $\begin{array}{l}\text { Provisional lease in } \\
\text { contracts for farmland and } \\
\text { material assets; } \\
\text { Unregistered farms; Firms; } \\
\text { Cooperative farms; } \\
\text { Consumers cooperatives; } \\
\text { Interlinked and barter } \\
\text { trade; }\end{array}$ & $\begin{array}{l}\text { Spotlight trade with } \\
\text { free-market prices; } \\
\text { Direct marketing; } \\
\text { Trade on wholesale } \\
\text { and terminal markets; } \\
\text { Commodity exchange } \\
\text { trade; } \\
\text { Trade with informal }\end{array}$ & $\begin{array}{l}\text { State and cooperative farms; } \\
\text { Organization under privatization, } \\
\text { liquidation and reorganization; } \\
\text { State regulation of wholesale and retail } \\
\text { prices; } \\
\text { Export licenses and quotas; } \\
\text { Import tariffs and duties; } \\
\text { State crediting of working capital for }\end{array}$ \\
\hline
\end{tabular}




\begin{tabular}{|c|c|c|c|}
\hline $\begin{array}{l}\text { for } \\
\text { sustainability }\end{array}$ & Credit cooperatives & $\begin{array}{l}\text { brands, origins, and } \\
\text { ecosystem services; } \\
\text { Free (monopoly) } \\
\text { agricultural water } \\
\text { pricing; } \\
\text { Clientalisation }\end{array}$ & $\begin{array}{l}\text { grain producers; } \\
\text { System of agro-market information; } \\
\text { Outdated system of social, economic, } \\
\text { and eco-regulations, monitoring and } \\
\text { information; } \\
\text { Foreign and international programs and } \\
\text { assistance projects; } \\
\text { State reserve }\end{array}$ \\
\hline \multicolumn{4}{|c|}{ Pre-accession to EU (2001-2006) } \\
\hline $\begin{array}{l}\text { Better defined } \\
\text { and badly } \\
\text { enforced rights } \\
\text { on agrarian and } \\
\text { eco-resources, } \\
\text { and contracts; } \\
\text { Harmonization } \\
\text { with EU } \\
\text { legislation and } \\
\text { standards }\end{array}$ & $\begin{array}{l}\text { Unregistered farms; Firms; } \\
\text { Cooperative farms; } \\
\text { Specialized and } \\
\text { multipurpose cooperatives; } \\
\text { Long-term contracts for } \\
\text { marketing against } \\
\text { innovation, credit, inputs } \\
\text { etc. supply; } \\
\text { Water User Associations; } \\
\text { Vertically integrated modes; } \\
\text { Professional associations; } \\
\text { Water Users Associations; } \\
\text { Credit Cooperatives }\end{array}$ & $\begin{array}{l}\text { Direct marketing; } \\
\text { Wholesale, terminal } \\
\text { and exchange markets } \\
\text { trades; } \\
\text { Trade with formal } \\
\text { brands, origins, } \\
\text { organic products, and } \\
\text { ecosystem services; } \\
\text { Free (monopoly) } \\
\text { agricultural water } \\
\text { pricing }\end{array}$ & $\begin{array}{l}\text { Product subsidies; } \\
\text { Preferential credit for investment } \\
\text { projects; } \\
\text { Preferential short-term crediting; } \\
\text { Special Accession Program for Agrarian } \\
\text { and Rural Development; } \\
\text { Regional programs for agrarian } \\
\text { development; } \\
\text { Cross-compliance requirement; } \\
\text { Quality and eco-regulations, standards, } \\
\text { and control agencies; } \\
\text { Regulations for organic farming; } \\
\text { Agricultural Advisory Service; } \\
\text { Harmonization of standards for quality, } \\
\text { safety, ecology etc. with EU; } \\
\text { Foreign and international programs and } \\
\text { assistance projects; } \\
\text { State reserve }\end{array}$ \\
\hline \multicolumn{4}{|c|}{ EU membership (Since January 1, 2007) } \\
\hline $\begin{array}{l}\text { Well-defined } \\
\text { rights, and } \\
\text { better } \\
\text { enforcement; } \\
\text { EU Community } \\
\text { Acquis; } \\
\text { Collective } \\
\text { institutions; } \\
\text { Monitoring and } \\
\text { sanctions from } \\
\text { EU }\end{array}$ & $\begin{array}{l}\text { Unregistered farms; Firms; } \\
\text { Cooperative farms; } \\
\text { Specialized and } \\
\text { multipurpose cooperatives; } \\
\text { Long-term inputs supply } \\
\text { and marketing contracts; } \\
\text { NGOs; } \\
\text { Codes of behaviour; } \\
\text { Diversification into } \\
\text { processing, services and } \\
\text { marketing; } \\
\text { Credit cooperatives; } \\
\text { Water User Associations; } \\
\text { Professional producers } \\
\text { organizations; } \\
\text { Vertically integrated modes; } \\
\text { Eco-associations, } \\
\text { Eco and other labels; } \\
\text { Protected origins and } \\
\text { brands }\end{array}$ & $\begin{array}{l}\text { Direct marketing; } \\
\text { Wholesale, terminal } \\
\text { and exchange markets } \\
\text { trades; } \\
\text { Trade with formal } \\
\text { brands, origins, } \\
\text { organic products, and } \\
\text { ecosystem services; } \\
\text { E-commerce with } \\
\text { agrarian products; } \\
\text { Free (monopoly) } \\
\text { agricultural water } \\
\text { pricing; } \\
\text { Insurance against } \\
\text { natural disasters }\end{array}$ & $\begin{array}{l}\text { Implementation of EU regulations and } \\
\text { standards; } \\
\text { EU Operational Programs; } \\
\text { National programs for eco-management } \\
\text { (lands, waters, waste, emissions, etc.); } \\
\text { NPARD; } \\
\text { Direct EU payments; } \\
\text { National tops-ups; } \\
\text { Export subsidies; } \\
\text { Milk quotas; } \\
\text { Advisory Service; } \\
\text { Regional programs for agrarian } \\
\text { development; } \\
\text { System of social, economic and eco- } \\
\text { monitoring, analysis and control; } \\
\text { Protected zones (NATURA); } \\
\text { Compensations for natural disasters; } \\
\text { Mandatory training for farmers; } \\
\text { Income and garbage taxation; } \\
\text { Support to trans-border initiatives; } \\
\text { Social security and assistance system; } \\
\text { State companies for research, } \\
\text { maintenance of eco-systems, etc. }\end{array}$ \\
\hline
\end{tabular}




\section{$6 \quad$ Elements and Levels of Analysis}

Analysis of the system and forms of governance is to be done for agrarian sustainability as a whole, and for each of its major aspects - economic, social, and ecological. In the latter case, that concerns relatively independent (sub)systems of governance of agriculture and society - economic management, social management, and environmental management.

For every subsystem, analysis further deepens for major elements - principles and components of agrarian sustainability. They are characterized with significant specificity in terms of governance needs, forms, factors, and efficiency. For instance, composite components of the governance of ecological sustainability are: (effective) management of soils, waters, atmosphere, biodiversity, landscape, climate, etc.; of economic sustainability: management of production and governance efficiency, adaptability, financial stability, etc. of farms and the sector; of social sustainability: amelioration of welfare of farmers, wellbeing of rural communities, etc.

Some of the specific forms of governance are relevant only for one aspect of agrarian sustainability, while others are integral and concern two or all of them. A particular mode is to be assessed independently only if it affects significantly social, economic, and ecological sustainability. In case that two or more forms of governance are complementary and impact sustainability jointly, they have to be evaluated together as a "package".

According to the specific objective the analysis of the system of governance of agrarian sustainability could (is to) be made at four different levels (Figure 1):

- individual - individual agrarian agents - owners of agrarian resources, farmers, hired labour, final consumers, state administration, etc.

- collective - complex farm (cooperative, partnership, corporation), specific organization (inputs supply, group eco-activity, etc.); particular ecosystem or region, etc.;

- national - certain subsector of agriculture, agriculture as a whole;

- trans-national - in regional, European, or global scale.

For each level relevant forms and mechanisms of governance of agrarian sustainability are to be identified and analysed. Specification of elements of the system of agro-governance in every level is to be done carefully. Some dominant forms at national or sectoral level may not be relevant for farms of a particular type. For instance, a great parts of EU CAP instruments do not impact at all the majority of Bulgarian farms due to impossibility for participation in public programs (formal restrictions, high costs), low interests, enormous difficulties and costs for detection of non-compliances and sanction by the authority, etc. At certain levels (farm, region) there may be no specific (formal) structure of governance of agrarian sustainability at all, which is to be carried by farms and farm organizations and/or the general system of management of the sector/country.

As a rule, effects and costs at a particular level and upper management levels are not simple sums of those of composite elements or lower levels of management. It is necessary to take into consideration the necessity of "collective actions" for achieving a minimal economic, social, ecological and technological size for a positive effect, mutual and multiplication effects and spillovers, contradictory effects and costs, and externalities in different subjects and management levels, in space and time horizon.

Agricultural farms are the main elements of the system of agrarian governance. That necessitates the evaluation of the comparative and absolute potential (internal incentives, capability, costs, intentions) of different type of farms (subsistent, semi-market, family, commissioned, cooperatives, corporation, public) for: sustainable agriculture and innovation, conservation and restoration of natural resources, long-term investment, minimization of direct and indirect negative effects, dealing with existing challenges, minimizing related costs and risks, effective adaptation, etc. Such an analysis is more complex for farms with complex internal structure (multimember partnerships, agricultural cooperatives, agri-corporations, public farms), which are characterized with division of ownership from management, and multiple owners and hired labour with diverse interests, personal preferences, capability, etc. For upper (farm) levels of management the governance of agrarian sustainability is either integrated in the main mechanisms of influence (requirement for "eco-compliance", "good agricultural practices) or it is a specialized structure (programs for income support, agro-ecology, mandatory standards for product quality and safety, working conditions, environmental protection, animal welfare). 


\section{$7 \quad$ Factors of Governance of Agrarian Sustainability}

Evolution of the system of governance of agrarian sustainability and choice of one or another form by agents depends on diverse economic, political, institutional, behavioral, technological, international, natural, etc. factors (Figure 2). For instance, type and evolution of forms of agro-management strongly depends on the personal characteristics of farmers and other participants- personal preferences, experiences, knowledge, capability, ideology, etc.

Another important factor is science and technological advancement, which determines the extent of knowledge of factors and consequences of sustainable development, gives further information on socioeconomic and ecological problems and risks (extent of degradation and pollution of natural environment, specific impact of different farms and technologies), and provides opportunities for effective management (improvement, adaptation) of diverse aspects of agrarian sustainability. Choice of governance form also depends on market and social demand (pressure) for sustainable exploitation of natural resources and agrarian development. Character of that demand depends on general socio-economic development, priority (social, economic, ecological) challenges at the current stage of development, opportunities for profiting and investment, and overall evolution of institutional environment (rules, standards, support, etc.).

Another important factor determining the system of governance are public (national, European) policies as well as implementation of international conventions and agreements related to different aspects of agrarian sustainability. For instance, a good part of Bulgarian farms adapt its production and technologies to new instruments (restrictions, standards, support) of EU CAP introduced after 2007. Finally, the system of governance of sustainability is affected by the "natural" evolution of natural environment (warming, extreme climate, drought), which imposes forms facilitating confrontation to negative trends and/or adaptation to natural changes.

Specific factors for governance of agrarian sustainability at the contemporary stage of development are to be identified and their importance and compatibility to agriculture, its subsectors, different regions, type of agri-ecosystems, farms, etc. analysed.

In a long term the level of agrarian sustainability, and economic, social, and ecological sustainability in agriculture, and the risks, conflicts and costs associated with them, depend on the efficiency of "established" system of governance in society, sector, region, economic organization, etc. However, in each specific moment or a shorter-period, the analysis could not always find adequate data and/or determine direct links between the system of governance (and its individual forms) and agrarian sustainability. The latter is caused by:

- time period (delay) between the management actions ("improvement" of governance), and the changes in agents behaviour, and the positive, negative or neutral effects on the state of agrarian sustainability and its individual aspects;

- "impossibility" for adequate assessment of all social, economic, and ecological aspects, and associated risks and costs, due to the lack of "full" knowledge on the state and processes of change in agrarian sector, rural areas and nature, the type of correlation with agrarian activities (in particular with new products and technologies, traditional organizations), and future costs associated with deterioration, restoration and conservation of agrarian structures, communities, and natural environment;

- insufficient factual data for social and economic process in rural areas ("viability') and the state and risks of natural environment (extent of eco-degradation and pollution in agriculture) due to the lack of monitoring, precise measurements, methodologies or studies in that area;

- "undervaluation" of social capital and natural resources by agents, social groups or society, and/or "lack" of system of governance of some aspects of agrarian sustainability. .

In order to overcome the above difficulties, individual governing forms are also evaluated by:

- $\quad$ how the forms affect behaviour of agents (intentions, actions, impacts)

- to what extent the forms induce individual behaviour and actions for maintenance and improvement of economic, social, and ecological function of the sector; 
- number (share) of agents they involve - i.e. to what extent the scale of activity (collective actions) contributes to the improvement of economic viability, social responsibility, and environmental performance of activity in entire agriculture.

It is necessary to take into consideration that the state and changes in socio-economic shape of agriculture, rural areas and natural environment are consequences not only of the system of management in a particular farms, region, subsector, or country, but other factors as well: overall demographic evolution (aging of population, depopulation of regions), impact of other industries (competition, financial crisis, contribution to global warming), natural evolution of environment, etc. Consequently, the real improvement or deterioration of the governance of agrarian sustainability in a particular farm, region, subsector, or country could be associated with a lack or controversial change in the level of agrarian sustainability at relevant levels and as a whole.

In many cases, it is impossible to "influence" economic, social or natural environment through (agro)management, and the effective adaptation is the only possible strategy for overcoming socioeconomic and ecological consequences for agriculture. Therefore, the potential of farms and sector for adaptation to constantly evolving market, institutional and natural environment is one of the main factor and indicator for assessment for agrarian sustainability [10]. At all levels of analysis diverse "external" and "internal" factors are to be identified and their importance is to be estimated in order to assess adequately efficiency of the system of agro-management and farm adaptation.

There is no "universal" form of governance equally applicable (efficient) for all aspects of agrarian sustainability and for all possible contingencies in which agrarian agents operate. Efficiency of individual modes is quite different since they have unlike potential to: provide adequate information, induce positive behaviour, reconcile conflicts and coordinate actions of parties, improve sustainability and mitigate risks, minimize overall management costs for agents with different preferences and capability, and in the specific (socio-economic, natural) conditions of each holding, eco-system, community, industry, region, and country. For instance, appropriate eco-information and training would be enough to induce voluntary actions by a "green" farmer, while most commercial enterprises would need outside incentives (price premium, cash compensation, punishment); market prices would coordinate well relations between water suppliers and users, while regulation of relations of water polluters and users would require a special private or public order; independent actions of farmers would improve the state of local eco-systems, while dealing with most regional, national, and global social and eco-challenges requires collective actions in large geographical and temporal scales, etc.

Individual governing modes are often alternative but not equally efficient for organization of activities [35]. Each form has distinct advantages and disadvantages to protect rights and investment, coordinate and stimulate socially desirable behaviour, explore economies of scale and scope, save production and transaction costs. Principally, free market has a big coordination and incentive advantages ("invisible hand", "power of competition"), and provides "unlimited" opportunities to benefit from specialization and exchange. However, market management could be associated with high uncertainty, risk, and costs due to lack (asymmetry) of information, low "appropriability" of some rights, price instability, and a great possibility for facing opportunistic behaviour and situation of missing and underdeveloped markets.

Special contract form ("private ordering") permits a better coordination and intensification of activity, and safeguard of agent's rights and investments. However, it may require large costs for specification and writing contract provisions, adjustments with constant changes in conditions, enforcement and disputing of negotiated terms, etc.

Internal organization allows a greater flexibility and control on activity (direct coordination, adaptation, enforcement, dispute resolution by a fiat). Extension of internal mode beyond smallpartnership boundaries, which allows achievement of minimum technological or ecological requirements, and exploration of scale and scope of economies, may lead to significant costs for development (finding partners, design, formal registration, restructuring), and current management (collective decision making, coordination of activity, control on coalition members opportunism, supervision and motivation of hired labour).

Separation of the ownership from management (cooperative, corporation, public farm/firm) gives enormous opportunities for growth in productivity and improvement of management efficiency - internal division and specialization of labour; achieving requirements of social and ecosystems; exploring scale and scope of economies; introduction of innovation; diversification; risk taking and sharing; investing in product promotion, brand names, relations with customers, counterparts and authorities. However, it 
could be connected with huge transaction costs for decreasing information asymmetry between managers and shareholders, for decision-making, and for adaptation, etc. Cooperative and non-for profit form also suffers from a low capability for internal long-term investment due to non-for-profit goals and nontradable character of shares (horizon problem). Evolution and maintenance of large collective organizations is usually associated with significant costs - for initiating, informing, collective decisionmaking and internal conflict resolution, controlling opportunism of current and potential members, modernization, restructuring, and liquidation.

Pubic forms often lead to high internal (internal administration and coordination) and outside (for other private and public agents) costs - for establishment, functioning, coordination, controlling, mismanagement, misuse by private and other agents, reorganization, and liquidation. Unlike market and private modes, for public organizations there is no automatic mechanism (competition) for selection of ineffective forms. Here public decision-making is necessary, which is associated with huge costs and time, and is often affected by strong private interests (lobbying groups, politicians and associates, bureaucrats, employees) rather than efficiency. Applying "market like" mechanisms in public sector (competition, auctions), and not pure (state) but more hybrid (public-private) forms is a way to overcome some disadvantages of public modes.

\section{Efficiency of Governance of Agrarian Sustainability}

Efficiency of the governance of agrarian sustainability represents the specific effectiveness in relation to the extent of realization of practically (technologically, agronomically, socially, politically, economically) possible level of social, economic, and ecological sustainability of agriculture, and the extent of minimization of the overall costs for management.

Assessment is made on overall efficiency and partial efficiency as the first one includes the system of governance as a whole, while the latter is for the main components (instruments) of management of social, economic and ecological sustainability.

According to the objectives and period (past, current, future) of analysis, and according to the available information, the assessment of efficiency of the system of governance or some of its element is for potential efficiency or actual efficiency. The former indicates the potential of the system or individual mode to change behaviour, action or impacts of agents for achieving agrarian sustainability, while the later shows the ultimate result (effect, impact, costs) in relation to agrarian sustainability.

Efficiency of the specific system of governance of agrarian sustainability eventually finds expression in certain level and dynamics of social, economic and ecological sustainability of agriculture. Accordingly a high or increasing agrarian sustainability means a high efficiency of the system of governance, and vice versa.

Agrarian sustainability and its individual aspects have many dimensions. In order to evaluate efficiency level of the governance it is necessary to work out an adequate system for assessment of social, economic, and ecological sustainability, and agrarian sustainability as a whole. Table 2 represents an example of a system of indicators for assessing the level of agrarian sustainability at sectoral level for the specific conditions of Bulgarian agriculture (Table 2). In another publication we presented a system for assessing sustainability of farms [36].

Table 2. Indicators for assessing agrarian sustainability at sectorial level in Bulgaria

\begin{tabular}{l|l|l}
\hline Economic Sustainability & Social Sustainability & Ecological sustainability \\
\hline Farm income of household/family & Annual working hours of farm labor & Share of investment for \\
working units; & Average age of employed; & environmental protection; \\
Gross margins in subsector/average & Equality in the status of man and & $\mathrm{CO}_{2}$ emissions; \\
for agriculture; & women; & Share of lands with erosion risk; \\
Net income/profit; & Remuneration of man and women & Share of follow up and permanent \\
Gross revenues/production costs & comparing to other sectors; & grasslands in utilized farmland; \\
comparing to average for agriculture; & Average remuneration of hired labor & Risk of pollution of ground \\
Productivity of farmland and & comparing to minimum in the & waters; \\
livestock; & country; & Varieties of crops and livestock; \\
\hline
\end{tabular}




\begin{tabular}{|c|c|c|}
\hline $\begin{array}{l}\text { Marketed output/own consumption; } \\
\text { Share of value added in subsector in } \\
\text { total agriculture }\end{array}$ & $\begin{array}{l}\text { Number of employed labor comparing } \\
\text { to all in agriculture; } \\
\text { Vacant positions comparing to all in } \\
\text { agriculture }\end{array}$ & $\begin{array}{l}\text { Variation in yields and output } \\
\text { comparing to agriculture }\end{array}$ \\
\hline
\end{tabular}

Source: Bachev and Ivanov [38]

In management practice and design it is often necessary to assess governance efficiency through potential efficiency, which allows timely assessment of its level, detection of low "efficiency" and possibility for augmentation, and measures for improvement of applied system. That is a consequence to the fact that often it is impossible or too expensive to collect needed information for some (or all) elements of efficiency, or it is impossible to determine quantitatively the contribution of a certain form to the final result. In these instances it is necessary to use a system of appropriate indicators for assessing the potential of individual modes for economically viable, socially responsible, and ecologically sustainable agricultural activity. However, improvement of activity is not always associated with progressive change in agrarian sustainability, due to low actual efficiency or impact of other factors. We must bear in mind that, certain governing forms have unlike applicability, benefits, and costs for different agents, and therefore dissimilar potential and incentives for improving agrarian sustainability. Table 3 presents an incomplete list of indicators for activity, which could be used for assessing potential efficiency of governing forms of economic, social and ecological sustainability (Table 3).

Assessment of absolute and comparative efficiency of the governance of agrarian sustainability is to be made. The former represents effectiveness in relation to the state before introduction of a particular form or improvement of the entire system. If sustainability as a result of the new system of governance is improving or its further deterioration is prevented, then the form is (more) efficient, and vice versa. For instance, evaluation is made on the impact of direct subsidies of EU CAP on levels of agrarian sustainability in new member states, including the efficiency of new "green payments" on eco-behaviour and ecological sustainability, contribution of NPARD measures for enhancing social, economic, and ecological sustainability of the sector, etc.

Table 3. Indicators for assessing potential efficiency of governance forms of agrarian sustainability

\begin{tabular}{l|l|l}
\hline Economic Sustainability & Social Sustainability & Ecological sustainability \\
\hline Share of marketed output; & Social initiatives of farms and & Implementation of efficient crop rotation; \\
Innovation activity; & agrarian organizations; & Implementation of Good Agricultural \\
Extent of implementation of & Extent of implementation of & Practices; \\
required agro-technique & working condition standards; & Introduction of professional codes of eco- \\
operations; & Extent of diversification of & behaviour and eco-standards; \\
Share of private investment; & activity; & Transition to eco or organic production; \\
Participation in public support & Share of women managers of & Introduced eco-products and services; \\
programs; & farms; & Amount of costs for environmental \\
Amount of public subsidies; & Number of hired labour; & protection; \\
Amount of direct foreign & Number of collective & Amount and coverage of signed public eco- \\
investment; & initiatives; & contracts; \\
Implementation of systems for & Membership in community & Membership in eco-cooperatives and \\
quality control; & and interests groups & associations; \\
Long-term inputs supply contract; & organizations; Dynamics of & Number and coverage of agro-ecological \\
Long-term contract for marketing & labour remuneration; & payments; \\
of output; & Extent of social assurance; & Amount and share of uncultivated farmland; \\
Membership in farm organization; & Amount of costs for social & Number of type of animals per unit \\
Training of personnel; & development & farmland; \\
Number of protected origins, & & Amount of chemicals for crop protection \\
brand names etc. & & total and per unit of utilized farmland \\
\hline
\end{tabular}

Comparative efficiency shows effectiveness (effects, costs) of a particular form or Pharmacology \& Pharmacy system of governance in relation to another alternative form (system). It is necessary to 
assess if it is practically possible an alternative system of management, which is able to increase the level of agrarian sustainability or achieve certain level with less overall (private and public) costs. That approach is also used for comparison of two or more feasible forms in order to select the most efficient one(s). For instance, social and economic sustainability could be improved through a number of alternative modes of public intervention: direct income support to farmers based on product subsidies, decoupled subsidies for farms, preferential taxes and crediting, price regulation (water for irrigation, electricity, farm produce), trade measures (export subsidies, quotas, tariffs), indirect support (free training, state services), etc. Similarly, ecological sustainability could be increased through public support to eco-associations, public eco-contracts, general and specific (green, unfavourable regions) direct payments, etc. The comparative efficiency of each of this form evaluates the comparative advantages and disadvantages (additional costs, additional farm, social, and ecological effect) in respect to alternative forms.

At management decision stage, the analysis of comparative efficiency is the means for selecting the most-efficient option of management of agrarian sustainability (behaviour, investment, cooperation, benefits) between institutionally, financially, and technologically possible alternative forms. Therefore, they are tools for increasing the absolute efficiency of the governance.

It is necessary to distinguish and assess the short-term, mid-term and long-term efficiency of the system of governance of agrarian sustainability. That is conditioned by the fact that the needs and conditions of governance change in time, while analysis is made in a particular moment or for certain period of time. Taking into account of "time" factor is done through evaluation of:

- short-term efficiency - usually up to 5 years or current programing period (7 years);

- mid-term efficiency - a relatively longer period of time (e.g. 5-10 years). The majority of European farmers are in advanced age and they are going to retire in coming years, that is why it is appropriate to use 8-12 years:

- long-term efficiency - in a foreseeable longer-term 12-15 and more years, which is to be greatly related with the conservation and transfer of agrarian resources to next generation(s).

When the effects, costs and efficiency of individual components of governance are evaluated it is necessary to take into account their different temporal scale, joitness, complementarity, controversies, temporal and social apartness, and potential for development in the conditions of constantly changing socio-economic and natural environment. Many assessments of efficiency usually include only direct costs and benefits, and ignore significant indirect costs and benefits. When evaluating governing forms the significant private and social transaction costs are often not fully considered, while they are critical for adequate assessment of efficiency [10]. Transaction costs are long-term (for design and introduction of a particular governing mode) and current (for using a particular form by different agents) factors.

Therefore, the assessment of the costs of governance should include:

- purely "production" costs and investment, which are associated with the technology of agrarian production, social development and natural conservation; and

- transaction costs, which are associated with the governance of relations with other agents - costs of finding labour, acquiring information, negotiation, organizational development, registration and protection of rights and products, controlling opportunism, conflicts resolution, adaptation to market and institutional environment, etc.

Assessment of public forms should include overall costs, which usually comprise: direct program costs of tax payers and/or assistance agency (for program management, funding of private and collective activity, control, reporting, disputing implementation), transacting costs (for coordination, stimulation, control of opportunisms and mismanagement) of bureaucracy, private and collective costs for individuals' participation in public modes (for adaptation, information, negotiation, paper works, payments of fees, bribes), costs for community control and reorganization (modernization, liquidation) of public forms, and (opportunity) "costs" of public inaction (negative effects on economy, human and animal health, lost biodiversity, etc.). 


\section{Improving the System of Governance of Agrarian Sustainability}

Most frequently, there is no perfect system of governance of agrarian sustainability and there are numerous socio-economic problems, challenges and risks associated with agrarian development [10]. What is more, certain level of social, economic and ecological sustainability often is achieved with too many costs for individual agents and society. At contemporary stage there is also a great dynamic of socio-economic and natural processes, which sooner or later makes the existing good working system of governance of agrarian sustainability "inefficient". All these require adequate alteration of the system of governance and its constant modernization. To a great extent the analyses and assessments of the system of governance and individual modes are conditioned by the needs to assist that process of improvement.

Improvement of the system of governance of agrarian sustainability should include the following stages (Figure 3): First, trends, factors and risks associated with agrarian sustainability are to be identified, and levels of social, economic and ecological sustainability in agriculture assessed. Modern science offers quite precise methods to assess the state and evolution of socio-economic processes and natural environment, and detect existing, emerging and likely challenges and risks [14]. The inexistence of serious social, economic, and ecological problems, conflicts and risks is an indicator suggesting that there is an effective system of governance of agrarian sustainability. However, usually there are significant or growing social, economic, and ecological problems and risks associated with agrarian development.

Second, it is necessary to assess the efficiency and potential of existing and other feasible modes and mechanisms of governance of agrarian sustainability, for overcoming existing, emerging and likely social, economic, and ecological problems and risks associated with agriculture. Analysis should embrace the system of governance and its individual components - institutional environment and various (formal, informal, market, private, contract, internal, outside, individual, collective, public, simple, complex, etc.) forms of governing activities of farms and other interested parties.

Efficiency of individual modes should be evaluated in terms of their absolute and comparative potential to safeguard and develop agents rights and investments, stimulate socially desirable level of rural welfare, economic growth and environmental protection activity, rapid detection of problems and risks, cooperation and reconciliation of conflicts, and save and recover total governing costs. Assessment should be also made on complementarities and/or contradictions between different governance forms e.g. high complementarities between (some) private, market and public forms of governance; conflicts between "gray" and "light" sector of agriculture, etc.

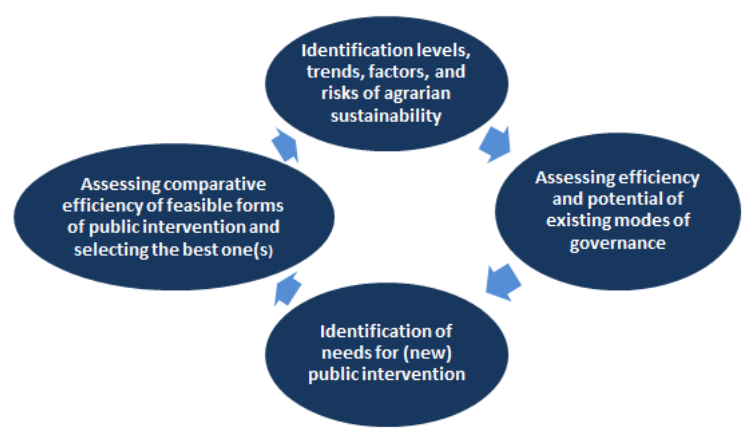

Figure 3. Stages for improvement of governance of agrarian sustainability

Efficiency checks should be performed periodically even when the system of governance of agrarian sustainability seems "working well". Good level of agrarian sustainability may be achieved at excessive social costs or further improvement of agrarian sustainability with the same social costs could be missed. In both cases there is a need to introduce an alternative more efficient organization of management. For instance, "state eco-management" (in terms of incentives, total costs, adaptation and investment potential) is often too expensive for taxpayers and could be replaced with more effective private, market or hybrid mode (public-private partnership). 
Third, deficiencies ("failures") of dominating market, private, and public modes are to be determined, and the needs for new public intervention in governance of agrarian sustainability are to be identified. The later could be associated with impossibility for achieving socially desirable and practically possible socio-economic and environmental goals, significant transaction difficulties and costs of participating agents, inefficient utilization of public and private resources, etc.

Finally, alternative modes for new public intervention able to correct (market, private and public) failures are to be identified, their comparative efficiency and complementarities should be assessed, and the most efficient one(s) should be selected. Only practically (technically, agronomical, economically, politically, etc.) possible modes of new public intervention in governance for the specific socio-economic, organizational and natural environment at current stage of development are to be compared.

Suggested analysis is to be made at different levels (farm, eco-system, regional, sectors, national, international) according to the type of social, economic, and ecological challenges, and the scale of collective actions necessary to mitigate specific problems and risks. It is not one time exercise completing in the last stage with a perfect system of governance of agrarian sustainability. It is rather a permanent process, which is to improve the governing system along with evolution of socio-economic and natural environment, specific challenges and risks, individual and communities (social) awareness and preferences, and modernization of technologies, organizations, and institutional environment. Besides, public (local, national, international) failure is also possible (and often prevail) which brings us into the next cycle of improvement of governance of agrarian sustainability.

(New) public intervention is not always more efficient than the existing state. There are many examples, for inappropriate, over, under, not timely or too expensive public involvement at all levels. Here the public intervention either does not correct market and private sector failures, or corrects them with more total costs, or leads to new failures and additional costs. Therefore, criterion for assessment should reflect whether it is realizing socially desirable and practically possible social, economic and ecological goals (levels of agrarian sustainability) with minimum total costs (direct, indirect, private, public, production, ecological, transaction, etc.). Accordingly inefficiency indicates either failure to achieve objectives (possible level of sustainability, overcoming certain social problems, decreasing existing economic risks, reducing losses, restoration and amelioration of natural environment), or its accomplishment with excessive costs in comparison with other feasible form of governance.

Suggested analysis also enables us to predict likely cases of new public (local, national, international) failures. The later could be due to impossibility to mobilize sufficient political support and necessary resources for improvement of governance and/or ineffective design of governance system of otherwise "good" policies in the specific socio-economic environment of a particular region, sub-sector, ecosystem, etc. Since public failure is a feasible option its timely detection permits foreseeing persistence or rising of certain social, economic and environmental problems, and informing interested agents and community about associated risks.

\section{Conclusion}

Analysis of the system, factors, and efficiency of governance of agrarian sustainability are extremely important both in academic, and practical (policy, farm and business forwarded) respects. Nevertheless, in many countries such analyses are far behind the modern developments in theory, and the needs and evolution of agrarian practice.

Suggested framework for assessing the governance of agrarian sustainability is to de discussed and further improved. After that it could be used for identification and assessment of specific mechanisms and modes of governance of agrarian sustainability in a particular subsector, type of ecosystems, regions of a country, and entire agriculture in a country. However, it is necessary to collect additional microeconomic information for agrarian agent's preferences and behaviour, activities and efficiency of farming organizations, effects and impacts on social, community and natural environment, etc. The ultimate goal of this study is to improve farm management and strategies, and agricultural policies and forms of public intervention in agriculture. 


\section{References}

1. H. Bachev, "Mechanisms of Governance of Sustainable Development", Journal of Applied Economic Science, vol. 4, no 2, pp.169-184, 2009.

2. C. Barrett, "Fairness, stewardship and sustainable development", Ecological Economics, vol. 19, no 1, pp. 11-17, 1996.

3. M. De Molina, "Agroecology and Politics. How To Get Sustainability? About the Necessity for a Political Agroecology", Agroecology and Sustainable Food Systems, vol. 37, no1, pp. 45-59, 2013.

4. R. Epp, "The Agrarian Vision: Sustainability and Environmental Ethics", Journal of Agricultural \& Environmental Ethics, vol. 26, no 3, pp. 739-741, 2013.

5. C. Kremen, A. Iles, and C. Bacon, "Diversified Farming Systems: An Agroecological, Systems-based Alternative to Modern Industrial Agriculture", Ecology and Society, vol. 17, no 4, pp. 44, 2012.

6. J. Weigelt, A. Muller, H. Janetschek, K. Topfer, "Land and soil governance towards a transformational post-2015 Development Agenda: an overview", Current Opinion in Environmental Sustainability, vol. 15, pp. 57-65, 2015.

7. K. Zimmerer, "Agriculture, livelihoods, and globalization: The analysis of new trajectories (and avoidance of justso stories) of human-environment change and conservation", Agriculture and Human Values, vol. 24, no 1, pp. 916, 2007.

8. H. Bachev, "Governing of Finance Supply in Bulgarian Farms", Available: SSRN 903502, 2004.

9. H. Bachev, "Assessment of Sustainability of Bulgarian Farms", proceedings, XIth Congress of the European Association of Agricultural Economists, Copenhagen, 2005.

10.H. Bachev, Governance of Agrarian Sustainability. Nova Science Publishers, 2010.

11.H. Bachev, "Risk Management in Agri-food Sector", Contemporary Economics, vol. 7, no 1, pp. 45-62, 2013.

12.E. Berge and N. Stenseth (editors), (1998). Law and the Governance of Renewable Resources. Studies from Northern Europe and Africa. ICS Press, 1998.

13.S. Beerbaum, "Agricultural soil protection in Germany - social requirements and legal provisions", ZUCKERINDUSTRIE, vol. 129, no 9, pp. 636-638, 2004.

14.G. Daily, T. Söderqvist, S. Aniyar, K. Arrow, P. Dasgupta, P. Ehrlich, C. Folke, A. Jansson, B. Jansson, N. Kautsky, S. Levin, J. Lubchenco, K. Mäler, D. Simpson, D. Starrett, D. Tilman and B. Walker, "The value of nature and the nature of value", Science 289, 395-396, 2000.

15.C. Edwards, R.Lal, P.Madden, R.Miller and G.House (editors), Sustainable Agricultural Systems, Soil and Water Conservation Society, 2000.

16.EC, "A Framework for Indicators for the Economic and Social Dimensions of Sustainable Agriculture and Rural Development", European Commission, 2001.

17.FAO, "SAFA. Sustainability Assessment of Food and Agriculture Systems Indicators", FAO, 2013.

18.A. Farah and A. Gomez-Ramos, "Competitiveness vs. Sustainability: An Assessment of Profitability as a Component of an Approach on "Sustainable Competitiveness" in Extensive Farming Systems of Central Spain", Sustainability, vol. 6, no 11, pp. 8029-8055, 2014.

19.M. Garcia-Brenes, "Incidence of the European Union's Agricultural Policy on the Sustainability of Olive Cultivation in Andalusia, Spain", CUADERNOS DE DESARROLLO RURAL, vol. 9, no 68, pp. 87-103, 2012.

20.R. Lowrance, P. Hendrix, and E. Odum, "A hierarchical approach to sustainable agriculture, American Journal of Alternative Agriculture, vol. 1, no 4, pp. 169-173, 1986.

21.N. Mirovitskaya and W.Ascher (editors), "Guide to Sustainable Development and Environmental Policy", Duke University Press, 2001.

22.OECD, "Environmental indicators for agriculture", Volume 3: Methods and Results, OECD, 2001.

23.S. Raman, "Agricultural Sustainability. Principles, Processes and Prospect", The Haworth Press Inc., 2006.

24.X. Sauvenier, J. Valekx, N. Van Cauwenbergh, E. Wauters, H. Bachev. K. Biala, C. Bielders, V. Brouckaert, V. Garcia-Cidad, S. Goyens, M. Hermy, E. Mathijs, B.Muys, M. Vanclooster and A. Peeters, "Framework for Assessing Sustainability Levels in Belgium Agricultural Systems - SAFE”, Belgium Science Policy, 2005.

25.UN, "Paris Climate Change Conference - November-December 2015", UN, 2015.

26.G. VanLoon, S. Patil and L. Hugar, "Agricultural Sustainability: Strategies for Assessment", SAGE Publications, 2005. 
27.M. Brklacich, C.Bryant and B.Smith, "Review and appraisal of concept of sustainable food production systems", Environmental Management, vol. 15, no 1, pp. 1-14, 1991.

28.L. Hansen, "Is Agricultural Sustainability a Useful Concept", Agricultural Systems, no 50, pp. 117-143, 1996.

29.I. Lewandowski, M. Härdtlein, and M. Kaltschmitt, "Su"stainable crop production: definition and methodological approach for assessing and implementing sustainability", Crop science, no 39, pp.184-193, 1999.

30.S. Lopez-Ridauira, O. Masera, and M. Astier, "Evaluating the sustainability of complex socio-environmental systems. The MESMIS framework", Ecological indicators no 2, pp. 135-148, 2002.

31.D. Hayati, Z. Ranjbar, and E. Karami, "Measuring Agricultural Sustainability", in E. Lichtfouse (ed.), Biodiversity, Biofuels, Agroforestry and Conservation Agriculture, Sustainable Agriculture Reviews 5, Springer Science, 73-100, 2010 .

32.R. Coase, "The Problem of Social Costs", Journal of Law and Economics, no 3, pp. 1-44, 1960.

33.E. Ostrom, "Governing the Commons: The Evolution of Institutions for Collective Action", Cambridge University Press, 1990.

34.D. North, "Institutions, Institutional Change and Economic Performance," Cambridge: Cambridge University Press, 1990.

35.O. Williamson," The Mechanisms of Governance", Oxford University Press, 1996.

36.H. Bachev, "A Framework for Assessing Sustainability of Farming Enterprises", Journal of Applied Economic Sciences, vol. 9, no 1, pp. 24-43, 2016.

37.H. Bachev and T.Nanseki, "Environmental Management in Bulgarian Agriculture - Risks, Modes, Major Challenges", Journal of the Faculty of Agriculture of Kyushu University, vol. 53, no 1, pp. 363-373, 2008.

38.H. Bachev and B.Ivanov, "Framework for Analyzing and Assessing the System of Governance and Levels of Agrarian Sustainability", available: SSRN 2700057 